\title{
Soil dry aggregate size distribution: effects of soil type and land use
}

\author{
V. Ćirić1 ${ }^{*}$, M. Manojlović ${ }^{1}$, Lj. Nešić ${ }^{1}$, M. Belić ${ }^{1}$ \\ ${ }^{I}$ Department for Field and Vegetable Crops, Faculty of Agriculture, University of Novi Sad, Trg Dositeja \\ Obradovića 8, 21000 Novi Sad, Serbia. ${ }^{*}$ Corresponding author: vciric@polj.uns.ac.rs
}

\begin{abstract}
Soil structure is an important physical property of soil and has a great impact on the environment and agriculture. Dry aggregate size distribution and related soil structure indices are essential parameters in understanding the structural state of the soil. This study was conducted to determine the effects of different soil types and land uses on structure parameters and to relate them to selected soil properties. The investigation was performed on five soil types (Arenosols, Fluvisols, Chernozems, Gleysols and Solonetz), each from three different locations and under three different land uses (cropland, meadow and forest), so that a total of 135 undisturbed soil samples were collected. Dry sieving analysis was performed to obtain eight aggregate size classes (ASCs) $(>10,10-5,5-3,3-2,2-1,1-0.5,0.5-0.25$ and $<0.25 \mathrm{~mm})$. The results suggest a highly significant impact of soil type on all ASCs and structure indices. Land use has a highly significant impact on the >10, 5-3 and 3-2 mm ASCs. Chernozems and Gleysols have more favorable structure than Arenosols, Fluvisols and Solonetz. Long term cultivation leads to the deterioration of soil structure and the formation of clods. Forest soils have a significantly better structure than soils under meadows and croplands. The application of principal component analysis and regression models identifies water retention at $-33 \mathrm{kPa}$, bulk density and $\mathrm{pH}$ value as for the most important factors in predicting dMWD and dGMD.
\end{abstract}

Keywords: Soil structure, dry aggregate size distribution, soil type, land use, soil organic carbon. 


\section{Introduction}

Soil structure is a key factor in soil fertility and agricultural productivity and thus has great ecological importance. The influence of soil structure on crust formation, root penetration, soil water and air movement, $\mathrm{CO}_{2}$ emission, erosion, nutrient retention and biological activity is well known. Soil structure, in turn, depends on the interaction of soil type, aggregating agents, soil management and environmental conditions (Tisdall and Oades, 1982; Oades and Waters, 1991; Bronick and Lal, 2005).

Soil structure is usually expressed as the degree of aggregate stability in water. Numerous studies have been conducted on the effects of land use change on aggregate stability (Neufeldt et al., 1999; Hoyosa and Comerford, 2005; Williams and Petticrew, 2009), but notably less attention has been devoted to dry aggregate size distribution (dASD) and the factors affecting it.

Dry ASD is one of the major physical characteristics of soil, and it strongly affects soil fertility and its resistance to erosion and degradation. It is also considered to be an indicator of soil structure. The importance of dASD is most often linked to the susceptibility of soil to wind erosion, which is strongly influenced by the size of the soil aggregates, especially in arid and semiarid environments. Pachepsky and Rawls (2003) emphasize the potential of dASD in improving pedotransfer functions. It is certain that dASD acts as a valuable soil property for evaluating tillage research. Previous studies indicate that the influence of soil properties on dASD must be analyzed on the basis of management and soil type (Colazo and Buschiazzo, 2010). One of the most common indices of dASD is dry mean weight diameter (dMWD). High values of dMWD usually indicate high water permeability and air capacity but lower erodability of soil. In countries in Eastern Europe, the structural coefficient (Ks) is principally used to describe the structural status of soils (Shein et al., 2001; Smirnova et al., 2006). This coefficient stresses the proportion of agronomically valuable fractions $(10-0.25 \mathrm{~mm})$ in relation to the proportion of $>10$ and $<0.25 \mathrm{~mm}$ fractions. The content of agronomically valuable fractions is one of the main soil quality indicators and is particularly important because valuable fractions provide optimal porosity and water and air capacity of soil (Medvedev and Cybulko, 1995; Shein et al., 2001).

Soil aggregation may also be expressed by dry geometric mean diameter (dGMD). As it is strongly related to the erodible fraction of soil, this indicator of structure can be used for predicting wind erodibility (Campbell, 1993).

Although the dynamics of terrestrial ecosystems depend on natural cycles, they can be directly modified by human activities (e.g., land-use/cover change) (IPCC, 2000). Land use change causes environmental changes that affect soil fertility. In most European countries, major land use changes occurred long ago. All of these changing processes contribute to soil degradation, which has become a major environmental problem. In their natural states, forests, grasslands and meadows have good soil structure and are rich in soil organic carbon (SOC), but their conversion to arable land usually leads to deterioration of the structure and then rapid erosion (Six et al., 1998; DeGryze et al., 2004). Soil structure usually deteriorates together with SOC. Structure deterioration has local, regional and global effects on economics, the quality of the environment and resource sustainability; moreover, it induces soil compaction and a decline in SOC (Lal, 1991). Increasing the intensity of cultivation can reduce $\mathrm{C}$-rich macroaggregates and increase $\mathrm{C}$-depleted microaggregates, resulting in an overall loss of SOC (Six et al., 2000). Although the fact that conventional ploughing causes damage to soil structure is well esta- 
blished (Pagliai et al., 2004), there is insufficient data on this damage obtained by dry sieving, especially comparing different soil types simultaneously.

The objective of this study is to evaluate the effects of long term land use regimes and different soil types on dASD and indices of soil structure. We hypothesized that the structure of the soil is more favorable in the soils under forests and meadows than it is in croplands that have been exposed to long term intensive tillage. Additionally, we expected soil type to have a strong effect on soil aggregation and structure indices.

\section{Materials and methods}

\subsection{Site description}

The present study was carried out in the Province of Vojvodina, which occupies the northernmost part of Serbia. Vojvodina covers an area of 2,150,600 ha and is a region characterized by intensive agriculture with a conventional tillage system. Located in the southernmost part of the Pannonian Basin $\left(46^{\circ} 11^{\prime}-46^{\circ} 37^{\prime} \mathrm{N}\right.$, $\left.18^{\circ} 51^{\prime}-21^{\circ} 33^{\prime} \mathrm{E}\right)$, Vojvodina represents the warmest and driest part of the basin. The mean annual temperature is $11.0^{\circ} \mathrm{C}$, with a mean of 88 frost days. Mean annual precipitation is $602 \mathrm{~mm}$ and mean annual relative humidity is $76 \%$. The topography of Vojvodina is predominantly characterized by loess terraces $(70-90 \mathrm{~m}$ altitude), loess and sand plateaus (90-120-200 m altitude) and river plains (Danube, Tisza and Sava rivers).

Soil genesis and evolution in the Province of Vojvodina have been strongly influenced by bioclimatic factors, the moderate continental climate and steppeforest vegetation. As the parent material, loess and alluvial deposits are responsible for the formation of very fertile soils in this region. Vojvodinian loess has a loamy texture and contains relict quartz (50-70\%), feldspar and clay (10-20\%) and $\mathrm{CaCO}_{3}(20-30 \%)$. The high $\mathrm{CaCO}_{3}$ content of soils formed on loess protects them from degradation even in regions with $700 \mathrm{~mm}$ precipitation. Alluvial deposits are mainly calcareous and vary from sandy to clayic. Only a small area has aeolian sands or rocks as the parent material.

Over the 200 years of ecosystem transformation from natural steppe-forest to the current state dominated by conventional tillage, soil degradation has become evident. The soil fertility is reduced by the destructive effects of heavy mechanization and the burning of harvest residues. All the investigated croplands have been under a conventional tillage system for $>100$ years. The most common crop rotation in the region consists of corn, wheat and soybeans. Meadows mainly contain a combination of mezophytes (Poa pratensis, Dactylis glomerata, Bromus mollis, Festuca pratensis, Cirsium arvense) and grasses (Poa sp., Stipa sp., Festuca sp., Cynodon sp., Panicum sp.) except in areas with alkaline and saline soils, where halophytes (Agropyrum repens, Matricaria chamomilla, Roripa kerneri, Chenopodium rubrum, Rumex crispus) dominate. The total area of deciduous forests and forestlands is mostly represented by Fagus sp., Quercus sp., Populus sp. and Salix sp.. Overall, the Province of Vojvodina is predominately agricultural land $(1,790,000$ ha or $83 \%)$, most of which is cropland $(1,650,000$ ha or $77 \%)$. Meadows and grasslands are very rare. Forest area comprises 140,717 ha, so the actual level of afforestation amounts to only $6 \%$.

\subsection{Soil sampling and preparation}

We decided to conduct our investigation on the five most common soil types in the region: Arenosols, Fluvisols, Chernozems, Vertisols and Solonetz (IUSS Working Group WRB, 2006). The selected soil types have a relatively wide range of soil properties even within single type (Table 1).

To assure the geographic representation of soil in the region, every soil type was sampled from three di- 
fferent locations in Vojvodina and at each location under three different land uses (cropland, meadow and forest). Sampling distances between different land use areas were no higher than $200 \mathrm{~m}$ to ensure comparability at every location. Undisturbed soil samples were taken from 0-20 cm from each land use category with three replicates approximately $10 \mathrm{~m}$ apart. Hence, a total of 135 samples were taken from 45 sampling points for soil structure analysis. A coring method with $100 \mathrm{~cm}^{3}$ cylinders was applied to take undisturbed soil samples, which were used for measuring bulk density. All other analyses were performed on disturbed soil samples, air dried and sieved through a $2 \mathrm{~mm}$ sieve ( $0.2 \mathrm{~mm}$ for SOC analysis).

\subsection{Soil analysis and calculation}

Dry ASD was determined by the standard dry-sieving method (Savinov, 1936). Briefly, $500 \mathrm{~g}$ of air-dried, undisturbed sample is sieved through a nest of sieves having $10,5,3,2,1,0.5$, and $0.25 \mathrm{~mm}$ square openings so eight aggregate size classes (ASCs) are obtained $(>10$, $10-5,5-3,3-2,2-1,1-0.5,0.5-0.25$ and $<0.25 \mathrm{~mm}$ ).

Using the weights of these ASCs, dMWD ( $\mathrm{mm})$ is calculated (Hillel, 2004):

$$
\mathrm{dMWD}=\sum_{i=1}^{n} \mathrm{x}_{i} \mathrm{w}_{i}
$$

where $w_{i}$ is the weight percentage of each ASC with respect to the total sample and $x_{i}$ is the mean diameter of each ASC (mm).

Dry GMD (mm) is calculated as (Hillel, 2004):

$\mathrm{dMWD}=\exp \left[\sum_{i=1}^{n} \frac{\left(\mathrm{w}_{\mathrm{i}} \log \left(\mathrm{x}_{\mathrm{i}}\right)\right)}{\mathrm{w}_{1}}\right]$

where $w_{i}$ is the weight percentage of each ASC with respect to the total sample and $\mathrm{x}_{\mathrm{i}}$ is the mean diameter of each ASC (mm).

Aggregate size distribution, expressed as the structure coefficient (Ks), is calculated according to (Shein et al., 2001):

$$
\mathrm{Ks}=\mathrm{a} / \mathrm{b}
$$

where a represents the weight percentage of aggregates $0.25-10 \mathrm{~mm}$ and $\mathrm{b}$ represents the weight percentage of aggregates $<0.25 \mathrm{~mm}$ and $>10 \mathrm{~mm}$.

The distribution of particle sizes was measured by sieving and using the pipette method, with sodium pyrophosphate as a dispersing agent. Soil water retention was measured at matric potentials of -33 and $-1500 \mathrm{kPa}$ using a porous plate and pressure membrane apparatus.

Soil $\mathrm{pH}$ values were measured potentiometrically in a 1:2 soil-water suspension. Content of $\mathrm{CaCO}_{3}$ was determined gas-volumetrically using a Scheibler apparatus. Soil organic carbon concentration was measured by a dichromate wet oxidation method.

\begin{tabular}{|c|c|c|c|c|c|c|c|c|c|c|}
\hline \multirow{2}{*}{$\begin{array}{l}\text { Soil type } \\
\text { / Location }\end{array}$} & \multicolumn{3}{|c|}{$\begin{array}{c}\text { Particle-size } \\
\text { distribution (\%) }\end{array}$} & \multirow{2}{*}{$\begin{array}{c}\text { BD } \\
\left(\mathrm{Mg} \mathrm{m}^{-3}\right)\end{array}$} & \multirow{2}{*}{$\begin{array}{c}\text { TP } \\
(\%)\end{array}$} & \multicolumn{2}{|c|}{$\begin{array}{c}\text { Water retention } \\
(\mathbf{k P a})\end{array}$} & \multirow{2}{*}{$\begin{array}{c}\mathrm{SOC} \\
\left(\mathrm{g} \mathrm{kg}^{-1}\right)\end{array}$} & \multirow{2}{*}{$\mathrm{CaCO}_{3}(\%)$} & \multirow{2}{*}{ pH } \\
\hline & TS & $\mathbf{S}$ & C & & & -33 & -1500 & & & \\
\hline \multicolumn{11}{|l|}{ Arenosols } \\
\hline Deliblato & 68 & 17 & 15 & 1.35 & 45 & 19.6 & 7.8 & 17.1 & 3.8 & 7.80 \\
\hline Kelebia & 80 & 7 & 13 & 1.34 & 40 & 12.0 & 7.1 & 23.5 & 8.9 & 7.17 \\
\hline
\end{tabular}

Table 1. Mean values $(n=9)$ of observed soil properties in different soil types at investigated localities. 


\begin{tabular}{|c|c|c|c|c|c|c|c|c|c|c|}
\hline \multirow{2}{*}{$\begin{array}{l}\text { Soil type } \\
\text { / Location }\end{array}$} & \multicolumn{3}{|c|}{$\begin{array}{c}\text { Particle-size } \\
\text { distribution (\%) }\end{array}$} & \multirow{2}{*}{$\begin{array}{c}\text { BD } \\
\left(\mathrm{Mg} \mathrm{m}^{-3}\right)\end{array}$} & \multirow{2}{*}{$\begin{array}{c}\text { TP } \\
(\%)\end{array}$} & \multicolumn{2}{|c|}{$\begin{array}{c}\text { Water retention } \\
(\mathrm{kPa})\end{array}$} & \multirow{2}{*}{$\begin{array}{c}\text { SOC } \\
\left(\mathrm{g} \mathrm{kg}^{-1}\right)\end{array}$} & \multirow{2}{*}{$\mathrm{CaCO}_{3}(\%)$} & \multirow{2}{*}{ pH } \\
\hline & TS & $\mathbf{S}$ & C & & & -33 & -1500 & & & \\
\hline Palic & 84 & 6 & 10 & 1.47 & 41 & 8.6 & 5.2 & 16.0 & 5.0 & 8.05 \\
\hline \multicolumn{11}{|l|}{ Fluvisols } \\
\hline $\mathrm{Kac}$ & 48 & 33 & 19 & 1.22 & 44 & 27.1 & 11.8 & 26.4 & 18.2 & 7.72 \\
\hline Veternik & 46 & 40 & 14 & 1.56 & 35 & 21.1 & 9.9 & 15.0 & 0.0 & 6.75 \\
\hline Novi Becej & 22 & 43 & 35 & 1.17 & 50 & 38.0 & 23.1 & 23.9 & 2.4 & 7.74 \\
\hline \multicolumn{11}{|l|}{ Chernozems } \\
\hline R. Sancevi & 36 & 34 & 30 & 1.47 & 46 & 29.5 & 16.8 & 33.4 & 2.2 & 7.24 \\
\hline Ljutovo & 77 & 11 & 12 & 1.38 & 46 & 13.5 & 6.3 & 21.9 & 12.6 & 8.01 \\
\hline Lovcenac & 38 & 36 & 26 & 1.39 & 46 & 29.3 & 14.8 & 25.9 & 12.4 & 7.43 \\
\hline \multicolumn{11}{|l|}{ Gleysols } \\
\hline Mileticevo & 33 & 30 & 37 & 1.21 & 49 & 32.8 & 18.4 & 28.4 & 0.0 & 6.36 \\
\hline Becej & 12 & 30 & 58 & 1.10 & 56 & 48.9 & 32.8 & 67.0 & 0.0 & 6.70 \\
\hline S. Crnja & 26 & 39 & 35 & 1.30 & 49 & 35.5 & 18.8 & 42.5 & 2.8 & 6.99 \\
\hline \multicolumn{11}{|l|}{ Solonetz } \\
\hline Basaid & 27 & 32 & 41 & 1.37 & 46 & 35.0 & 19.7 & 29.8 & 4.2 & 7.44 \\
\hline $\mathrm{Bac}$ & 41 & 32 & 27 & 1.30 & 49 & 27.2 & 14.2 & 24.7 & 0.0 & 6.66 \\
\hline Kumane & 26 & 36 & 38 & 1.45 & 31 & 41.3 & 22.6 & 25.4 & 2.7 & 8.49 \\
\hline
\end{tabular}

(TS: Total sand; S: Silt; C: Clay; BD: Bulk density; TP: Total porosity).

\subsection{Statistical analysis}

The significance of treatments was determined using ANOVA. Fisher's LSD test was used to separate means at the $p<0.05$ level of significance. For establishing the relationship between soil properties and AASD and structure indices, correlation analysis was performed. Where correlations were significant, they tested at the $p<0.05, p<0.01$ and $p<0.001$ level of significance. Principal component analysis (PCA) with rotated input values (varimax rotation) was performed to extract the soil properties with the highest factor loadings. It is expected that these soil properties have greater influence on structure indices. To develop regression equations, multiple regression analysis was used. All calculations were performed with data analysis software system Statistica 10.0, StatSoft, Inc.

\section{Results}

\subsection{Aggregate-size distribution}

The ANOVA shows a highly significant $(p<0.001)$ effect of soil type on every ASC (Table 2). Land use and its interaction with soil type are highly significant at $p<0.001$ only for the $>10,5-3$ and 3-2 mm aggregates. Aggregate size classes of 2-1, 1-0.5 and 0.5-0.25 $\mathrm{mm}$ are not affected by land use.

Solonetz soils have a significantly higher content of $>10 \mathrm{~mm}$ aggregates than the other soil types and more than $55 \%>5 \mathrm{~mm}$ aggregates (Table 3 ). Are- 
nosols and Chernozems have the fewest aggregates in the $>10 \mathrm{~mm} \mathrm{ASC}$, in contrast to the other soils. Fluvisols, Gleysols and Solonetz have significantly more aggregates in the 10-5 mm ASC. Chernozems and Gleysols have the highest content of aggregates in the 5-3, 3-2 and 2-1 mm ASCs, while Chernozems have the highest content in 1-0.5 mm ASC. Due to the large amount of sand in Arenosols, this soil has significantly and extremely high amounts of aggregates in the lowest ASCs $(0.5-0.25$ and $<0.25 \mathrm{~mm})$, unlike Gleysols, which have the fewest aggregates in $<0.25 \mathrm{~mm}$ ASC

Table 2. Analysis of variance for weight percent of aggregate-size classes.

\begin{tabular}{lcccccccc}
\hline \multirow{2}{*}{ EFFECT } & \multicolumn{7}{c}{ Aggregate-size class (mm) } \\
\cline { 2 - 9 } & $>\mathbf{1 0}$ & $\mathbf{1 0 - 5}$ & $\mathbf{5 - 3}$ & $\mathbf{3 - 2}$ & $\mathbf{2 - 1}$ & $\mathbf{1 - 0 . 5}$ & $\mathbf{0 . 5 - 0 . 2 5}$ & $<\mathbf{0 . 2 5}$ \\
\hline Soil type & $* * *$ & $* * *$ & $* * *$ & $* * *$ & $* * *$ & $* * *$ & $* * *$ & $* * *$ \\
Land use & $* * *$ & $*$ & $* * *$ & $* * *$ & $\mathrm{~ns}$ & $\mathrm{~ns}$ & $\mathrm{~ns}$ & $* *$ \\
Soil type $\times$ Land use & $* * *$ & $*$ & $* * *$ & $* * *$ & $* *$ & $\mathrm{~ns}$ & $\mathrm{~ns}$ & $\mathrm{~ns}$ \\
\hline
\end{tabular}

(ns: not significant; *: significant at $p<0.05 ; * *$ :significant at $p<0.01$.; ***:significant at $p<0.001$ ).

The proportion of aggregates of $>10 \mathrm{~mm}$ in the investigated soils decreases in the following order: croplands $>$ meadows $>$ forests. It is significantly lower in forest soils than meadows and croplands. Significantly fewer 3-2 mm aggregates are found in croplands. For the 5-3, 3-2 and $<0.25 \mathrm{~mm}$ ASCs, the content of aggregates decreases in the following order: forests $>$ meadows $>$ croplands. The amount of desirable 5-3 and 3-2 $\mathrm{mm}$ aggregates was substantially higher in forests and meadows than in croplands.

Table 3. Effects of soil type and land use on dry aggregate-size distribution.

\begin{tabular}{lccccccccc}
\hline \multirow{2}{*}{ Effect } & \multicolumn{8}{c}{ Aggregate size class $(\mathbf{m m})$} \\
\cline { 2 - 10 } & $>\mathbf{1 0}$ & $\mathbf{1 0 - 5}$ & $\mathbf{5 - 3}$ & $\mathbf{3 - 2}$ & $\mathbf{2 - 1}$ & $\mathbf{1 - 0 . 5}$ & $\mathbf{0 . 5 - 0 . 2 5}$ & $<\mathbf{0 . 2 5}$ \\
\hline Soil types & & \multicolumn{7}{c}{ Weight percent of aggregates } \\
\hline Arenosols & $5.87 \mathrm{c}$ & $8.44 \mathrm{c}$ & $7.23 \mathrm{c}$ & $5.25 \mathrm{c}$ & $8.11 \mathrm{~d}$ & $5.35 \mathrm{~b}$ & $39.64 \mathrm{a}$ & $20.11 \mathrm{a}$ \\
Fluvisols & $19.70 \mathrm{~b}$ & $27.55 \mathrm{a}$ & $15.81 \mathrm{~b}$ & $8.68 \mathrm{~b}$ & $10.40 \mathrm{bc}$ & $3.04 \mathrm{c}$ & $6.63 \mathrm{c}$ & $8.19 \mathrm{~b}$ \\
Chernozems & $9.07 \mathrm{c}$ & $18.11 \mathrm{~b}$ & $16.08 \mathrm{~b}$ & $11.10 \mathrm{a}$ & $15.45 \mathrm{a}$ & $7.15 \mathrm{a}$ & $16.19 \mathrm{~b}$ & $6.84 \mathrm{~b}$ \\
Gleysols & $17.01 \mathrm{~b}$ & $28.67 \mathrm{a}$ & $19.49 \mathrm{a}$ & $10.67 \mathrm{a}$ & $12.38 \mathrm{~b}$ & $3.66 \mathrm{bc}$ & $5.96 \mathrm{c}$ & $2.16 \mathrm{c}$ \\
Solonetz & $25.50 \mathrm{a}$ & $29.81 \mathrm{a}$ & $15.14 \mathrm{~b}$ & $7.84 \mathrm{~b}$ & $9.01 \mathrm{~cd}$ & $2.70 \mathrm{c}$ & $4.81 \mathrm{c}$ & $5.18 \mathrm{bc}$ \\
\hline Land use & & & & & & & & \\
\hline Croplands & $19.35 \mathrm{a}$ & $23.85 \mathrm{a}$ & $12.44 \mathrm{~b}$ & $7.47 \mathrm{~b}$ & $10.88 \mathrm{a}$ & $4.72 \mathrm{ab}$ & $15.10 \mathrm{a}$ & $6.19 \mathrm{~b}$ \\
Meadows & $16.10 \mathrm{a}$ & $20.77 \mathrm{a}$ & $14.83 \mathrm{ab}$ & $9.24 \mathrm{a}$ & $11.63 \mathrm{a}$ & $4.97 \mathrm{a}$ & $13.49 \mathrm{a}$ & $8.96 \mathrm{ab}$ \\
Forests & $10.84 \mathrm{~b}$ & $22.92 \mathrm{a}$ & $16.98 \mathrm{a}$ & $9.42 \mathrm{a}$ & $10.70 \mathrm{a}$ & $3.46 \mathrm{~b}$ & $15.35 \mathrm{a}$ & $10.34 \mathrm{a}$ \\
\hline
\end{tabular}

(Means between soil types in the same column followed by different letters are significantly different at $p<0.05$ using Fischer's LSD; Means between land uses in the same column followed by different letters are significantly different at $p<0.05$ using Fischer's LSD). 


\subsection{Structure indices}

Both soil type and land use have highly significant $(p<0.001)$ effects on dMWD (Table 4$)$, and their interaction was also significant $(p<0.01)$.

There are no significant differences in the dMWD of Gleysols and Fluvisols (Table 5). Solonetz have the highest dMWD, while Chernozems are significantly higher than Arenosols, which have the lowest values. Land use affects the dMWD in a significantly different manner and values decrease in the following order: croplands $>$ meadows $>$ forests.

Table 4. Analysis of variance for structure indices.

\begin{tabular}{lccc}
\hline EFFECT & $\begin{array}{c}\text { dMWD } \\
(\mathbf{m m})\end{array}$ & $\begin{array}{c}\text { dGMD } \\
\mathbf{( m m )}\end{array}$ & Ks \\
\hline Soil type & $* * *$ & $* * *$ & $* * *$ \\
Land use & $* * *$ & $* *$ & $* *$ \\
Soil type $\times$ Land use & $* *$ & $* *$ & $* *$ \\
\hline
\end{tabular}

(*: significant at $p<0.05$; **: significant at $p<0.01$; $* * *$ : significant at $p<0.001)$.

Soil type significantly affects the dGMD $(p<0.001)$, while land use and interaction also have significant effects $(p<0.01)$.

Dry GMD differs significantly among different soil types. Solonetz have the highest value and Arenosols have the lowest. Cropland differs significantly in its dGMD when compared to meadows and forests.

Table 5. Effects of soil type and land use on structure indices.

\begin{tabular}{lccc}
\hline Effect & $\begin{array}{c}\text { dMWD } \\
(\mathbf{m m})\end{array}$ & Ks & $\begin{array}{c}\text { dGMD } \\
(\mathbf{m m})\end{array}$ \\
\hline Soil types & & & \\
Arenosols & $2.87 \mathrm{~d}$ & $3.28 \mathrm{c}$ & $0.91 \mathrm{~d}$ \\
Fluvisols & $8.06 \mathrm{~b}$ & $2.81 \mathrm{c}$ & $1.78 \mathrm{c}$ \\
Chernozems & $4.91 \mathrm{c}$ & $7.05 \mathrm{a}$ & $1.39 \mathrm{~b}$ \\
\hline
\end{tabular}

\begin{tabular}{lccc}
\hline Effect & $\begin{array}{c}\text { dMWD } \\
(\mathbf{m m})\end{array}$ & Ks & $\begin{array}{c}\text { dGMD } \\
(\mathbf{m m})\end{array}$ \\
\hline Gleysols & $7.69 \mathrm{~b}$ & $5.34 \mathrm{~b}$ & $1.88 \mathrm{ab}$ \\
Solonetz & $9.60 \mathrm{a}$ & $3.27 \mathrm{c}$ & $2.04 \mathrm{a}$ \\
Land use & & & \\
Croplands & $7.58 \mathrm{a}$ & $3.51 \mathrm{~b}$ & $1.72 \mathrm{a}$ \\
Meadows & $6.69 \mathrm{~b}$ & $4.18 \mathrm{~b}$ & $1.59 \mathrm{~b}$ \\
Forests & $5.61 \mathrm{c}$ & $5.36 \mathrm{a}$ & $1.50 \mathrm{~b}$ \\
\hline
\end{tabular}

(Means between soil types in the same column followed by different letters are significantly different at $p<0.05$ using Fischer's LSD; Means between land uses in the same column followed by different letters are significantly different at $p<0.05$ using Fischer's LSD).

The effect of soil type on the structure coefficient is highly significant $(p<0.001)$. The effect of land use is also significant $(p<0.01)$, as is their interaction.

Chernozems have the highest Ks, a value that is significantly different in relation to Gleysols. Solonetz, Fluvisols and Arenosols have significantly lower values. Values of Ks increase in the following order: croplands $<$ meadows $<$ forests. There is a significant difference between forests and both meadows and croplands.

\subsection{Correlation analysis}

The investigated soil properties, the obtained ASCs and the structure indices were subjected to a correlation analysis, and the Pearson's correlation coefficients were determined (Table 6). The quantity of large macroaggregates $>10 \mathrm{~mm}$ is highly correlated $(p<0.001)$ with clay content $(\mathrm{r}=0.56)$, dMWD $(\mathrm{r}=$ $0.97)$, dGMD $(\mathrm{r}=0.88)$ and water retention at $-33 \mathrm{kPa}$ $(\mathrm{r}=0.49)$ but negatively correlated with $\mathrm{CaCO}_{3}$ content $(r=-0.39)$. Aggregate size classes of $10-5$ and $5-3 \mathrm{~mm}$ are strongly correlated with silt $(\mathrm{r}=0.76$ and $\mathrm{r}=0.70$, respectively) and clay $(\mathrm{r}=0.74$ and $\mathrm{r}=0.52)$ content and water retention at $-33(\mathrm{r}=0.73$ and $\mathrm{r}=$ 
$0.62)$ and $-1500 \mathrm{kPa}(\mathrm{r}=0.71$ and $\mathrm{r}=0.60)$. The quantity of aggregates in the 3-2 and 2-1 mm ASCs are correlated with silt fraction $(\mathrm{r}=0.57$ and $\mathrm{r}=0.38)$ and $\mathrm{Ks}(\mathrm{r}=0.67$ and $\mathrm{r}=0.62)$. Soil organic carbon and total porosity show a close relationship with 5-3 $(\mathrm{r}=0.60$ and $\mathrm{r}=0.43)$ and $3-2 \mathrm{~mm}(\mathrm{r}=0.49$ and $\mathrm{r}$ $=0.40)$ ASCs. Bulk density is negatively correlated with 5-3 $(\mathrm{r}=-0.52)$ and $3-2 \mathrm{~mm}(\mathrm{r}=-0.44)$ ASCs. Aggregate size class of $1-0.5 \mathrm{~mm}$ is most strongly correlated with the $2-1 \mathrm{~mm}(\mathrm{r}=0.69)$ ASC. The two smallest ASCs $(0.5-0.25$ and $<0.25 \mathrm{~mm})$ show a close correlation with total sand content $(r=0.79$ and $r$ $=0.71)$ but a negative correlation with water retention at $-33(\mathrm{r}=-0.74$ and $\mathrm{r}=-0.60)$ and $-1500 \mathrm{kPa}(\mathrm{r}$ $=-0.65$ and $\mathrm{r}=-0.58)$.
Dry MWD and GMD are positively and highly significantly correlated with clay $(r=0.67$ and $r=0.76)$ and silt $(r=0.58$ and $r=0.70)$ fraction and water retention at $-33(\mathrm{r}=0.62$ and $\mathrm{r}=0.71)$ and $-1500 \mathrm{kPa}$ $(\mathrm{r}=0.57$ and $\mathrm{r}=0.68)$ but negatively correlated with total sand $(\mathrm{r}=-0.68$ and $\mathrm{r}=-0.80)$ and $\mathrm{CaCO}_{3}(\mathrm{r}=$ -0.39 and $r=-0.40)$ content.

The structure coefficient is strongly correlated with the 5-3 $(\mathrm{r}=0.50), 3-2(\mathrm{r}=0.67)$, and $2-1(\mathrm{r}=0.62)$ ASCs. It is also correlated with the agronomically valuable aggregates $(\mathrm{r}=0.82)$ and significantly correlated with SOC content $(r=0.32)$ and the 1-0.5 $\operatorname{mm} \operatorname{ASC}(r=0.37)$. 


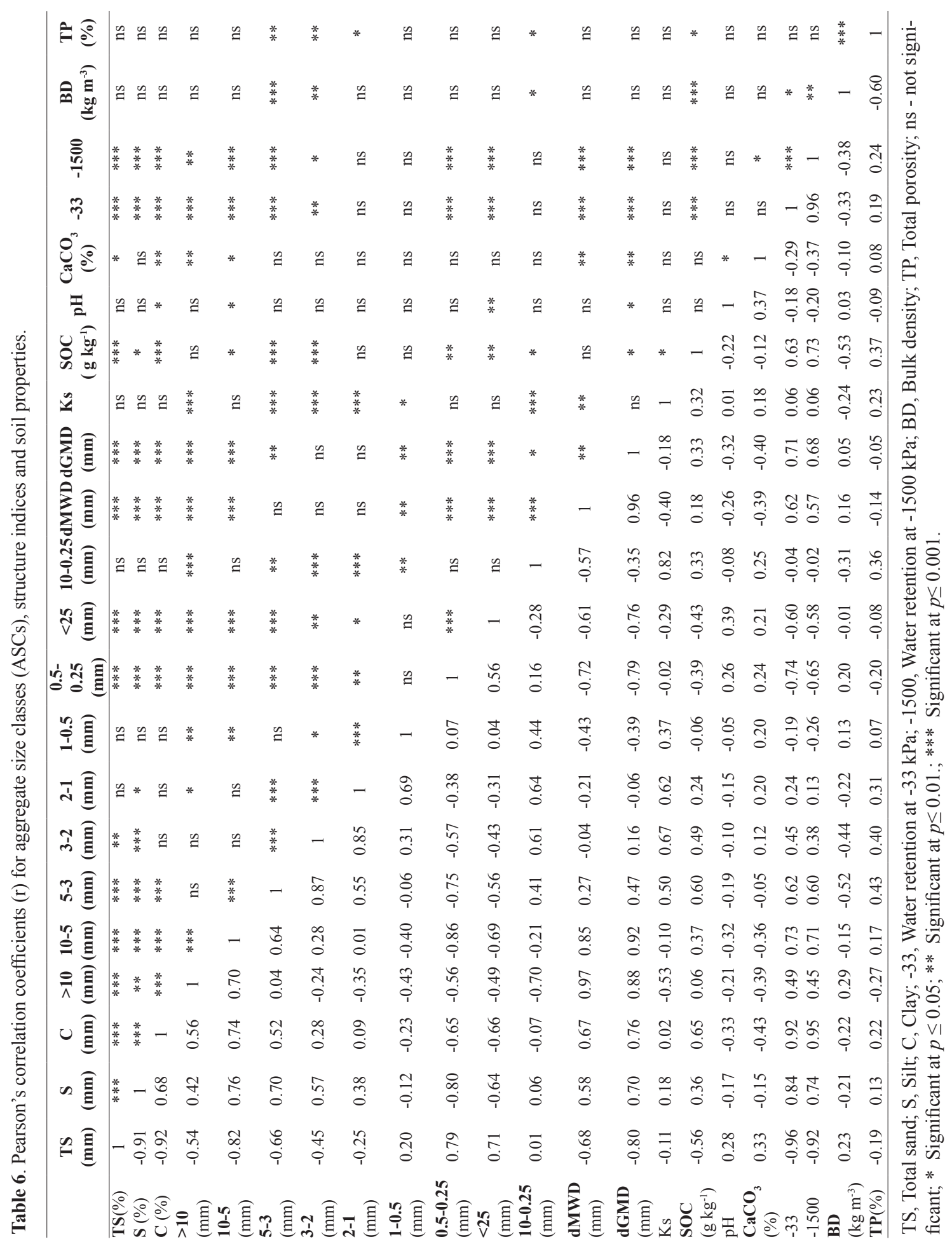




\subsection{Principal component analysis}

Ten soil properties were included in PCA to extract the smallest number of factors that can explain most of the total variation. Three factors extracted by PCA explained $82 \%$ of the total variance in the samples (Table 7). The first factor accounted for $54 \%$, the second for $17 \%$ and the third for $11 \%$. High loadings $(>0.70)$ in the first factor group had silt, clay, total sand and water retention at -33 and $-1500 \mathrm{kPa}$. The second fac- tor had a high factor loading for bulk density and total porosity, while the third factor had high factor loading for $\mathrm{CaCO}_{3}$ and $\mathrm{pH}$ value. Considering the fact that soil properties with the highest loadings within a single factor are highly correlated with each other, we chose the soil property with the highest loading from every single factor for multiple regression analysis. Thus we selected water retention at -33 , bulk density and $\mathrm{pH}$ value as representative soil properties for predicting structure indices.

Table 7. Factor loadings obtained by principal component analysis (varimax normalized rotation).

\begin{tabular}{lccc} 
& Factor 1 & Factor 2 & Factor 3 \\
\hline Eigen vectors & & & \\
\hline $\mathbf{S}(\%)$ & $\mathbf{0 . 8 9}$ & 0.02 & -0.02 \\
$\mathbf{C}(\%)$ & $\mathbf{0 . 8 8}$ & 0.18 & 0.34 \\
$\mathbf{T S}(\%)$ & $\mathbf{- 0 . 9 6}$ & -0.11 & -0.18 \\
$\mathbf{C a C O}(\%)$ & -0.26 & 0.18 & $\mathbf{- 0 . 7 6}$ \\
$\mathbf{B D}\left(\mathrm{Mg} \mathrm{kg}^{-1}\right)$ & -0.18 & $\underline{\mathbf{0 . 8 6}}$ & 0.10 \\
-33 & $\underline{\mathbf{0 . 9 6}}$ & 0.18 & 0.10 \\
-1500 & $\mathbf{0 . 9 2}$ & 0.27 & 0.19 \\
pH & -0.07 & -0.13 & $\mathbf{- 0 . 8 4}$ \\
SOC(g kg-1) & 0.54 & 0.60 & 0.17 \\
TP(\%) & 0.05 & $\mathbf{0 . 8 5}$ & 0.02 \\
\hline Eigenvalue & 5.39 & 1.69 & 1.13 \\
Total variance (\%) & 53.89 & 16.85 & 11.32 \\
Cumulative variance $(\%)$ & 53.89 & 70.75 & 82.07 \\
\hline
\end{tabular}

(TS: Total sand; S: Silt; C: Clay; -33: Water retention at -33 kPa; -1500: Water retention at -1500 kPa; BD: Bulk density; TP: Total porosity. Marked loadings are $>0.70$ ).

\subsection{Multiple regression analysis}

$\mathrm{dMWD}=-4.731+7.453(\mathrm{BD})+0.200(-33)-0.570(\mathrm{pH})$

Using multiple regression analysis, we developed regression equations for predicting both $\mathrm{dMWD}$ and dGMD. The equation to predict dMWD is highly significant at $p<0.001$ with a coefficient of determination $\mathrm{R}^{2}=0.55$.
The equation to predict dGMD is also highly significant at $p<0.001$, with a coefficient of determination $\mathrm{R}^{2}=0.63$.

$\mathrm{dGMD}=0.297+0.912(\mathrm{BD})+0.337(-33)-0.116(\mathrm{pH})$ 
Soil properties extracted by PCA are not significantly related to Ks.

\section{Discussion}

\subsection{Soil type and soil structure}

The relationship between soil aggregation and soil type is complex. Soil structure results from the mutual impact of several factors. Soil type does not directly affect soil structure, but the intrinsic combinations of soil properties that define soil type strongly influence its aggregation and therefore the soil structure. Dry ASD depends not only on the cultivation method but also on soil properties (Kemper and Rosenau, 1986). We observed each soil type as the result of specific soil properties which affect the soil structure.

The highly significant $(p<0.001)$ effects of soil type on all ASCs and the structure indices (dMWD, dGMD and Ks) suggest their crucial influence on dASD. All recorded dGMD values are very similar and highly correlated to dMWD $(r=0.96)$.

Solonetz have the most soil in the $>5 \mathrm{~mm}$ ASCs and, logically, the highest dMWD $(9.60 \mathrm{~mm})$ and dGMD $(2.04 \mathrm{~mm})$. As a result of the high clay and sodium contents in these soils, current processes such as peptization, swelling and shrinkage lead to the formation of large aggregates. Clay has a great influence on dASD, acting as a cementation substance. Clay content is the most important inherent property of soil that influences the fractal parameter D (Perfect et al., 1993). We found a highly significant correlation $(p<0.001)$ between clay and dMWD $(r=0.64)$ and clay and dGMD $(r=0.73)$. Solonetz have poorer structure $(\mathrm{Ks}=3.27)$ than Chernozems and Gleysols.

The lowest values of dMWD $(2.87 \mathrm{~mm})$ and dGMD $(0.91 \mathrm{~mm})$ appear as a consequence of the fact that Arenosols have the most soil in the $<0.5 \mathrm{~mm}$ ASCs due to the high sand content and the lack of binding substances such as SOC or clay. Sand content is negatively correlated with dMWD $(r=-0.65)$ and dGMD $(r=-0.75)$. Arenosols as initial soils still show soil loss by wind erosion as a result of insufficient aggregation $(\mathrm{Ks}=3.28)$.

We found that Chernozems have a dMWD of 4.91 $\mathrm{mm}$. Yang and Wander (1998) found that dMWD ranged from 7.11 to $8.82 \mathrm{~mm}$ in Illinois Mollisol exposed to different tillage treatments. Vojvodinian Chernozem is considered to be a well-structured soil (Ćirić, 2008). Additionally, we found in this soil the highest content $(84.09 \%)$ of agronomically valuable aggregates $(10-0.25 \mathrm{~mm})$ that are highly correlated with the $3-2(r=0.61)$ and 2-1 $(r=0.64)$ ASCs. A high proportion of agronomically valuable aggregates corresponds to soils with optimal total porosity and water air capacity. We obtained a significant correlation between SOC and agronomically valuable aggregates ( $\mathrm{r}$ $=0.33$ ). Similar results were presented by Smirnova et al., (2006). Higher Ks refer to a better structural state of the soil. The index of the agronomically valuable fractions Ks is clearly highest in Chernozems (7.05). The presence of cementing agents $\left(\mathrm{CaCO}_{3}\right.$, moderate clay content, worms and mollic humus deposited from steppe vegetation) creates the good structure of Chernozems. We found a negative correlation between $\mathrm{CaCO}_{3}$ and $\mathrm{dMWD}(\mathrm{r}=-0.39)$, which implies a positive impact of $\mathrm{CaCO}_{3}$ on forming desirable aggregates. Bronick and $\mathrm{Lal}(2005)$ reported that $\mathrm{CaCO}_{3}$ increases aggregation in semiarid environments.

Fluvisols also have an increased content of nondesirable large aggregates $(>5 \mathrm{~mm})$. This finding agrees with the results of Gajić et al. (2010). Only Fluvisols and Gleysols are not significantly different with regard to $\mathrm{dMWD}$, and they have similar values (8.06 and $7.69 \mathrm{~mm}$ ). The lack of cementing agents and occasional flooding maintain Fluvisols in initial states, making them unstructured, as confirmed by their having the lowest mean Ks (2.81). These results are in contrast 
with Tobiašová (2011), who found a more favorable soil structure in Fluvisols than in Chernozems.

The distribution of ASCs in Gleysols is very similar to that of Fluvisols. A high proportion of large aggregates is related to the high clay content found in the investigated Gleysols. However, Gleysols (Ks $=5.34$ ) have a good structure, unlike Fluvisols. This finding is most likely due to the notably higher SOC concentration in Gleysols than in Fluvisols.

Just as the SOC is seen as one of the most important properties affecting wet aggregate stability (Bird et al., 2002), we found that clay content and water retention at -33 and $-1500 \mathrm{kPa}$ are the soil properties most highly correlated with dASD. Similar findings are presented by Skidmore and Layton (1992). Considering the fact that dMWD and dGMD are strongly correlated with clay $(r=0.67$ and $r=0.76)$ and silt $(r=$ 0.58 and $r=0.70)$ fractions and water retention at -33 $(\mathrm{r}=0.62$ and $\mathrm{r}=0.71)$ and $-1500 \mathrm{kPa}(\mathrm{r}=0.57$ and $\mathrm{r}$ $=0.68)$, they could be very valuable for modeling soil susceptibility to wind erosion. In addition, if a higher Ks acts as an indicator of a better structure, its strong correlation with 5-3 $(r=0.50), 3-2(r=0.67)$ and 2-1 $(r=0.62)$ ASCs stresses the importance of these ASCs for improving soil structure.

\subsection{Land use and soil structure}

The conversion of natural ecosystems to cultivated ones has often resulted in a decrease in soil quality. We established that land use highly affects only the $>10,5-3$ and 3-2 mm ASCs. The influence of land use was highly significant $(p<0.001)$ on dMWD and significant $(p<0.01)$ on both dGMD and Ks.

Among land use categories, dMWD is significantly different and decreases in the following order: croplands $(7.58 \mathrm{~mm})<$ meadows $(6.69 \mathrm{~mm})<$ forests $(5.61 \mathrm{~mm})$. Soils under native vegetation (meadows and forests) have a substantially higher amount of desirable aggregates (5-3 and 3-2 mm ASCs) compared to croplands. This finding implies a negative impact of long term tillage on dASD and thus on soil structure. Croplands have $78 \%$ more aggregates $>10$ $\mathrm{mm}$ than soils under native forest and $20 \%$ more than native meadows. Meadows have more aggregates $>10$ $\mathrm{mm}$ because of occasional grazing or hay mowing activities. This finding clearly indicates that dASD differs for different land uses and that tillage creates undesirable aggregates $>10 \mathrm{~mm}$. As a result of compaction by agricultural machinery with long term tillage, the soil has more large aggregates (clods) (Wiesmeier et al., 2012). Colazo and Buschiazzo (2010) emphasize the large and stable aggregates (pseudo-aggregates or clods) in fine-textured soils exposed to cultivation and their effectiveness in mitigating wind erosion. Large aggregates are not favorable for improving the soil structure and increase bulk density while reducing the water retention capacity (Boix-Fayos et al., 2001). Noellemeyer et al. (2008) recorded a 30\% loss of intermediate ASCs after long term cultivation. According to our results, more pronounced negative effects of cultivation are found in macro ASCs $(>0.25$ mm). Tisdall and Oades (1980) and Gupta and Germida (1988) stated that fungal biomass is a key factor in the formation of macroaggregates and emphasized the sensitivity of macro ASCs and their nutrient and microbial content $(0.25$ to $1.00 \mathrm{~mm})$ to long term cultivation, while micro ASCs are stabilized by organic matter. However, our findings also show a significant $(p<0.01)$ impact of long term cultivation on the micro $\operatorname{ASC}(<0.25 \mathrm{~mm})$.

In contrast to dMWD, dGMD values do not exhibit significant differences between meadow (1.59 $\mathrm{mm})$ and forest $(1.50 \mathrm{~mm})$, but cropland has a significantly higher value $(1.72 \mathrm{~mm})$. The best soil structure is found in forests $(\mathrm{Ks}=5.36)$, with poorer structure in meadows and croplands $(\mathrm{Ks}=4.18$ and $\mathrm{Ks}=3.51)$, a result that confirms those of Tobiašová (2011). 
Forests also have more agronomically valuable aggregates. The favorable structure of forest soils is a consequence of an increased organic matter and the lack of damage from agricultural mechanization present in croplands. We can emphasize that continuous long term tillage induces higher values of undesirable aggregates (clods) and dMWD. This finding suggests that the conversion of native forest and meadow vegetation to long term cropped soil leads to the deterioration of soil structure.

\subsection{Multivariate and regression analysis}

The PCA is successfully used to group soil properties into three independent factors that explain $82 \%$ of the cumulative sample variance. Jagadamma et al., (2008) also used a combination of PCA-derived soil properties and multiple regression analysis for predicting corn yield. The equations we developed are highly significant for predicting dMWD and dGMD. We obtained water retention at -33 , bulk density and $\mathrm{pH}$ value as defining variables for $\mathrm{MMWD}$ and dGMD. Yoo et al. (2011) used bulk density as a parameter in the equation to predict dMWD. A predictive equation cannot be established for Ks because the soil properties extracted by PCA had no significant effect on Ks. This finding might result from the higher correlation between Ks and SOC than between Ks and the properties extracted by PCA.

\section{Conclusions}

Dry aggregate size distribution and soil structure indices (dMWD, dGMD and Ks) depend on soil type and land use in a semiarid environment.

Sandy soils such as Arenosols have low aggregation because of the high amounts of sand and the lack of binding agents. Fluvisols have higher clay content and thus better aggregation than Arenosols. Chernozems and Gleysols have the most favorable structure. These soils have the most agronomically valuable aggregates due to the presence of numerous cementing agents. Solonetz contain more large aggregates (clods) because of their high sodium and clay content.

Long term tillage strongly affects soil structure in croplands, leading to higher values of undesirable aggregates (clods), which imply higher dMWD (7.58 $\mathrm{mm})$ in comparison to meadows $(6.69 \mathrm{~mm})$ and forests $(5.61 \mathrm{~mm})$. Forest soils have the most favorable structure because they have high organic matter content and an undisturbed surface horizon, unlike croplands. Meadows are well-structured but contain more large aggregates.

Dry MWD and GMD are strongly associated with the clay and silt content as well as with water retention at -33 and $-1500 \mathrm{kPa}$, while $\mathrm{Ks}$ is significantly correlated with SOC.

Highly significant regression equations for predicting both dMWD and dGMD are developed. It is concluded that multiple regression analysis in combination with PCA can be applied to assess the dMWD and dGMD.

\section{Acknowledgements}

This work was carried out as part of a Ph.D. thesis by Vladimir Ćirić and was supported by the Serbian Ministry of Education and Science (project TR 31027). We would like to thank Professor Borivoj Pejić for his support and valuable suggestions for this paper. Thanks should also go to the staff of the Faculty of Agriculture, University of Novi Sad for their technical assistance. 


\section{References}

Bird, S.B., Herrick, J.E., Wander, M.M., Wright, S.F. 2002. Spatial heterogeneity of aggregate stability and soil carbon in semi-arid rangeland. Environ. Poll. 116, 445-455.

Boix-Fayos, C., Calvo-Cases, A., Imeson, A.C. 2001. Influence of soil properties on the aggregation of some Mediterranean soils and the use of aggregate size and stability as land degradation indices. Catena. 44, 47-67.

Bronick, C.J., Lal, R. 2005. Soil structure and management: a review. Geoderma. 124, 3-22.

Campbell, C.A., Moulin, A.P., Curtin, D., Lafond, G.P., Townley-Smith, L. 1993. Soil aggregation as influenced by cultural practices in Saskatchewan: I. Black Chernozemic soils. Can. J. Soil Sci. 73, 579-595.

Ćirić, V. 2008. Water-physical properties of chernozem, as a fertility factor in corn production. Magister's thesis, University of Novi Sad, Serbia, 178 p (In Serbian).

Colazo, J.C., Buschiazzo, D.E. 2010. Soil dry aggregate stability and wind erodible fraction in a semiarid environment of Argentina. Geoderma. 159, 228-236.

DeGryze S., Six J., Paustian K., Morris S.J., Paul E.A., Merckx R. 2004. Soil organic carbon pool changes following land-use conversions. Global Change Biol. 10, 1120-1132.

Gajić, B., Đurović, N., Dugalić, G. 2010. Composition and stability of soil aggregates in Fluvisols under forest, meadows, and 100 years of conventional tillage. J. Plant Nutr. Soil Sci.173, 502-509.

Gupta, V.V.S.R., Germida, J.J. 1988. Distribution of microbial biomass and its activity in different soil aggregate size classes as affected by cultivation. Soil Biol. Biochem. 20, 777-786.
Hillel, D. 2004. Introduction to Environmental Soil Physics. Elsevier, Amsterdam, 494 p.

Hoyosa, N., Comerford, N.B. 2005. Land use and landscape effects on aggregate stability and total carbon of Andisols from the Colombian Andes. Geoderma. 129, 268-278.

IPCC, 2000. Land Use, Land-Use Change and Forestry. Cambridge University Press, UK, 375 p.

IUSS Working Group WRB, 2006.A Framework for International Classification, Correlation and Communication. Food and Agriculture Organization of the United Nations, Rome, 128 p.

Jagadamma, S., Lal, R., Hoeft, R.G., Nafziger, E.D., Adee, E.A. 2008. Nitrogen fertilization and cropping system impacts on soil properties and their relationship to crop yield in the central Corn Belt, USA. Soil Tillage Res. 98, 120-129.

Kemper, W. D., Rosenau, R. C. 1986. Aggregate stability and size distribution. In: A. Klute (ed). Methods of Soil Analysis, Part 1. Physical and Mineralogical Methods. American Society of Agronomy, Madison, WI, USA, pp: 425-444.

Lal, R. 1991. Soil structure and sustainability. J. Sustain. Agric. 1, 67- 92.

Medvedev, V.V., Cybulko, W.G. 1995. Soil criteria for assessing the maximum permissible ground pressure of agricultural vehicles on Chernozem soils. Soil Till. Res. 36, 153-164.

Neufeldt, H., Ayarza, M.A., Resckc, D.V.S., Zech, W. 1999. Distribution of water-stable aggregates and aggregating agents in Cerrado Oxisols. Geoderma. 93, 85-99.

Noellemeyer, E., Frank, F., Alvarez, C., Morazzo, G., Quiroga, A. 2008. Carbon contents and aggregation related to soil physical and biological properties under a land-use sequence in the semiarid region of central Argentina. Soil Till. Res. 99, 179-190. 
Oades, J. M., Waters, A. G. 1991. Aggregate hierarchy in soils. Aust. J. Soil Res. 29, 815-828.

Pachepsky, Y.A., Rawls, W.J. 2003. Soil structure and pedotransfer functions. Eur. J. Soil Sci. 54, 443-452.

Pagliai, M., Vignozzi, N., Pellegrini, S. 2004. Soil structure and the effect of management practices. Soil Till. Res. 79, 131-143.

Perfect, E., Kay, B.D., Ferguson, J.A., da Silva, A.P., Denholm, K.A., 1993. Comparison of functions for characterizing the dry aggregate size distribution of tilled soil. Soil Till. Res. 28, 123-139.

Savinov, N.O. 1936. Soil Physics. Sielchozgiz Press, Moscow (in Russian).

Shein, Y.V., Arhangel'skaya, T.A., Goncharov, V.M., Guber, A.K.,Pochatkova, T.N., Sidorova, M.A., Smagin, A.V., Umarova, A.B. 2001. Field and laboratory methods of physical properties and soil status investigations. The University of Moscow, Russia, 199 p. (in Russian).

Six J., Elliott E.T., Paustian K., Doran J.W. 1998. Aggregation and soil organic matter accumulation in cultivated and native grassland soils. Soil Sci. Soc. Am. J. 62, 1367-1377.

Six, J., Paustian, K., Elliott, E.T., Combrink, C. 2000. Soil Structure and Organic Matter: I. Distribution of Aggregate-Size Classes and Aggregate-Associated Carbon. Soil Sci. Soc. Am. J. 64, 681-689.
Skidmore, E.L., Layton, J.B. 1992. Dry soil aggregate stability as influenced by selected soil properties. Soil Sci. Soc. Am. J. 56, 557-561.

Smirnova, LG., Novykh, L.L., Pelekhotse, E.A. 2006. Physical properties of chernozems on slopes in the landscape farming system. Eurasian Soil Sci. $39,278-282$.

Tisdall, J.M., Oades, I.M. 1980. The effect of crop rotation on aggregation in a red-brown earth. Aust. J. Soil Res. 18, 423-434.

Tisdall, J. M., Oades, I. M. 1982. Organic matter and water-stable aggregates in soils. J. Soil Sci. 62, 141-163.

Tobiašová, E. 2011. The effect of organic matter on the structure of soils of different land uses. Soil Till. Res. 114, 183-192.

Wiesmeier, M., Steffens, M., Mueller, C.W., Kölbl, A., Agnieszka, R., Peth, S., Horn, R., KögelKnabner, I. 2012. Aggregate stability and physical protection of soil organic carbon in semi-arid steppe soils. Eur. J. Soil Sci. 63, 22-31.

Williams, N.D., Petticrew, E.L. 2009. Aggregate stability in organically and conventionally farmed soils. Soil Use Manage. 25, 284-292.

Yoo, G., Yang, X.M., Wander, M.M. 2011. Influence of soil aggregation on SOC sequestration: a preliminary model of SOC protection by aggregate dynamics. Ecol. Eng. 37, 487-495. 
